All102 624020

REFERENEE PUBLICATIONS

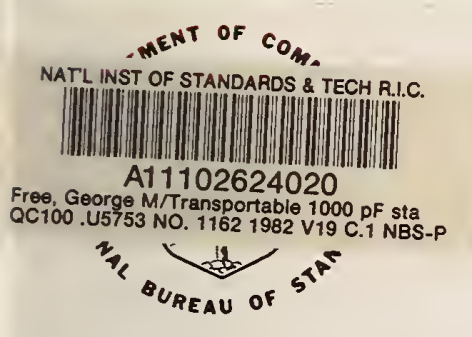

NBS TECHNICAL NOTE 1162

U.S. DEPARTMENT OF COMMERCE/National Bureau of Standards

\title{
Transportable 1000 pF Standard for the NBS Capacitance Measurement Assurance Program
}

QC

100

.45753

\#1162

1982 


\section{NATIONAL BUREAU OF STANDARDS}

The National Bureau of Standards' was established by an act of Congress on March 3, 1901. The Bureau's overall goal is to strengthen and advance the Nation's science and technology and facilitate their effective application for public benefit. To this end, the Bureau conducts research and provides: (1) a basis for the Nation's physical measurement system, (2) scientitic and technological services for industry and government, (3) a technical basis for equity in trade, and (4) technical services to promote public safety. The Bureau's technical work is performed by the National Measurement Laboratory, the National Engineering Laboratory, and the Institute for Computer Sciences and Technology.

THE NATIONAL MEASUREMENT LABORATORY provides the national system of physical and chemical and materials measurement; coordinates the system with measurement systems of other nations and furnishes essential services leading to accurate and uniform physical and chemical measurement throughout the Nation's scientific community, industry, and commerce; conducts materials research leading to improved methods of measurement, standards, and data on the properties of materials needed by ind ustry, commerce, educational institutions, and Government; provides advisory and research services to other Government agencies; develops, produces, and distributes Standard Reference Materials; and provides calibration services. The Laboratory consists of the following centers:

\section{Absolute Physical Quantities ${ }^{2}$ - Radiation Research - Chemical Physics - Analytical Chemistry - Materials Science}

THE NATIONAL ENGINEERING LABORATORY provides technology and technical services to the public and private sectors to address national needs and to solve national problems; conducts research in engineering and applied science in support of these efforts; builds and maintains competence in the necessary disciplines required to carry out this research and technical service; develops engineering data and measurement capabilities; provides engineering measurement traceability services; develops test methods and proposes engineering standards and code changes; develops and proposes new engineering practices; and develops and improves mechanisms to transfer results of its research to the ultimate user. The Laboratory consists of the following centers:

Applied Mathematics - Electronics and Electrical Engineering ${ }^{2}$ - Manufacturing Engineering - Building Technology - Fire Research - Chemical Engineering ${ }^{2}$

THE INSTITUTE FOR COMPUTER SCIENCES AND TECHNOLOGY conducts research and provides scientific and technical services to aid Federal agencies in the selection, acquisition, application, and use of computer technology to improve effectiveness and economy in Government operations in accordance with Public Law 89-306 (40 U.S.C. 759), relevant Executive Orders, and other directives; carries out this mission by managing the Federal Information Processing Standards Program, developing Federal ADP standards guidelines, and managing Federal participation in ADP voluntary standardization activities; provides scientific and technological advisory services and assistance to Federal agencies; and provides the technical foundation for computer-related policies of the Federal Government. The Institute consists of the following centers:

Programming Science and Technology - Computer Systems Engineering.

'Headquarters and Laboratories at Gaithersburg, MD, unless otherwise noted;

mailing address Washington, DC 20234.

${ }^{2}$ Some divisions within the center are located at Boulder, CO 80303. 
George Free and Jerome Morrow

Electrical Measurements and Standards Division National Bureau of Standards

Washington, DC 20234

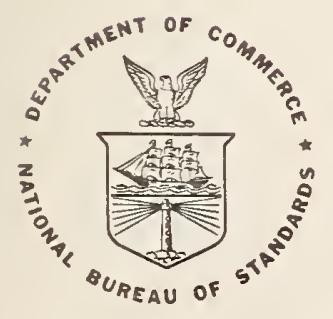

U.S. DEPARTMENT OF COMMERCE, Malcolm Baldrige, Secretary

NATIONAL BUREAU OF STANDARDS, Ernest Ambler, Director

Issued October 1982 
National Bureau of Standards Technical Note 1162

Natl. Bur. Stand. (U.S.), Tech. Note 1162, 15 pages (Oct. 1982) CODEN: NBTNAE 


\author{
George Free and Jerome Morrow \\ Electrical Measurements and Standards Division \\ National Bureau of Standards \\ Washington, DC 20234
}

\title{
Abstract
}

A capacitance transport standard has been constructed for use in the National Bureau of Standards Measurement Assurance Program. The transport standard was designed so that variations in ambient temperature and mechanical shock would have a minimal effect on the value of the internal reference capacitors. A significant improvement in stability of 1000 pF capacitors during shipment and in the laboratory has been achieved through this design.

Key words: calibration; measurement assurance; measurement assurance programs; reference standards; standard capacitors; standard qualification; transfer standards.

\section{Introduction}

The National Bureau of Standards Measurement Assurance program (MAP) in electrical units has been in existence for several years. In this program, NBS transport standards are shipped to customer laboratories and calibration of the customer's reference standards is done in place. The accuracy of the calibration procedure depends on the degree of knowledge of the value of the NBS transport standard while it is at the customer's laboratory; this is optimized by analysis of measurements made at NBS before and after the period of time the standard is at that laboratory. If the value of the transfer standard is known accurately, the advantages to the laboratory are threefold: reduction of down-time due to the absence of reference standards, greater confidence in the values of laboratory standards, and documentable verification of the customer's measurement process through the test procedure.

For the capacitance MAP, it was necessary to develop a transport standard which would behave predictably over an extended period during which the internal capacitors would be subjected to both mechanical and thermal shock. Due to customer needs, the transport standard would have to be at the 1000 pF level (the most common reference standard in most laboratories).

At the $1000 \mathrm{pF}$ level, the most stable, commerciallyavailable standards are nitrogen dielectric capacitors. The values of these capacitors vary due to temperature (with coefficients of about $\left.2 \mathrm{ppm} /{ }^{\circ} \mathrm{C}\right)$, temperature hysteresis, and mechanical stress. The reduction of instability from these sources were planned through design of the transport box and minor modifications to commercially available capacitors.

The goals for the construction of the transport package were a s follows: 
The package should provide a transportable temperature controlled environment with a maximum departure from nominal temperature of $0.01{ }^{\circ} \mathrm{C}$ under normal laboratory conditions.

- The package should provide for a minimum amount of change due to handiing.

o The package should be of simple design and construction so that it may be duplicated by laboratories interested in increasing the stability of their standards.

\section{Construction}

The most important limitation in the performance of the transport standard is the quality of the capacitor used. Tests were devised by which the mechanical stability of capacitors could be systematically evaluated (1) and the results were used to select the four "best" capacitors available for inclusion in the standard. The method of testing and the results are discussed in the Appendix. These tests were also used to evaluate $10 \mathrm{pF}$ and $100 \mathrm{pF}$ standards.

Before placing the capacitors in the transport box, their outer enclosures were removed. Since the stability of the trimmer in these capacitors is unknown and difficult to analyze, it was also removed and electrical connection to the inner enclosure was made through a special head. The head was designed to eliminate stray capacitance between the leads coming out of the capacitor and to guarantee good electrical contact between the cable shield and the enclosure, thus making the capacitor more closely meet the requirements for three-terminal devices with a negligible amount of stray capacitance.

The capacitors were placed in an aluminum box (see Figure 1) $25.4 \mathrm{~cm}$ ( 10 inches) on a side, with sufficient soft-sponge packing material surrounding them so that they were effectively fixed in position with no rigid connections. The capacitors were insulated from each other by plastic sheets, thereby reducing the possibility of electrical ground loops during measurements. Heaters, consisting of many turns of magnet wire, were positioned to cover the total surface of each side of the box and were attached to the box with adhesive tape (adhesive agent on both sides). Additional tape (of the type used to seal heating air ducts) was tightly wrapped on top of the heater wires to assure good thermal contact with the box and prevent motion of the wire. An outer box was made out of plastic and wood, its dimensions allowing for at 1 east $7.6 \mathrm{~cm}$ ( 3 inches) of insulation between it and the inner box. The aluminum box was then foamed in place with rigid polyurethane. Coaxial leads from the inner box to the outside were placed so, as to assure good thermal contact with the inside aluminum box, reducing temperature variations transmitted through the leads. The coaxial leads are RG316/U 50 ohm cable. The small cross-section of metal in the inner conductor and shielding reduces the heat path to the outside. 
The temperature control circuit for the standard (see Figure 2) consists of a thermistor bridge and a very simple operational amplifier circuit. The temperature-sensitive components of the control circuit (resistors and amplifier) are placed inside the aluminum box in a section separated from the capacitors by an aluminum plate. The less sensitive components, such as the power supply and the power transistor for the heating coils, are in a small control box separate from the transport standard. The control thermistor is wrapped in aluminum foil and placed under the adhesive tape between the heater wires and the aluminum enclosure.

A temperature measuring device consisting of a thermistor bridge with variable decade resistors in one arm was constructed. The thermistor was placed on top of and taped to one of the capacitors.

The control circuit was designed to operate from 110 VAC or a 12 VDC primary power source. When operated from a DC power source, the circuit needs an additional +15 VDC battery to provide current for the operational amplifier.

\section{Performance}

As the standard was too large to fit in available environmental chambers, the temperature-variation performance could be studied only with respect to changes in the laboratory environment. The temperature variation tests were carried out over a relatively narrow range of temperatures.

For a temperature range of $3.9{ }^{\circ} \mathrm{C}$ in the laboratory, i.e., from 19.9 ${ }^{\circ} \mathrm{C}$ to $23.8{ }^{\circ} \mathrm{C}$, the measured variation in box temperature was $0.011^{\circ} \mathrm{C}$ while, for a temperature variation of $1.3{ }^{\circ} \mathrm{C}$ from $19.9{ }^{\circ} \mathrm{C}$ to $21.2{ }^{\circ} \mathrm{C}$, the measured variation was $0.005^{\circ} \mathrm{C}$. These two tests were carried out in different laboratory environments.

Tests correlating change in capacitance with temperature variations were first carried out using the measurement system described in (1). The standards were intercompared with 100 pF fused silica dielectric capacitors which were in a temperature controlled air bath. The small apparent changes in value of the transport standard could not definitely be attributed to the transport standard alone due to possibilities of error in the rest of the system.

The reported measurements of temperature dependence were obtained using the measurement system described in (2) and 100 pF quartz dielectric capacitors in an oil bath as the reference standard. The results of the stability test are shown in Table 1. The period during which measurements were made was one month (31 days). There were 17 intercomparisons and the time-of-day of measurement was varied in order that the full range of laboratory temperatures, i.e., 19.9 to $21.1{ }^{\circ} \mathrm{C}$, was included. The 


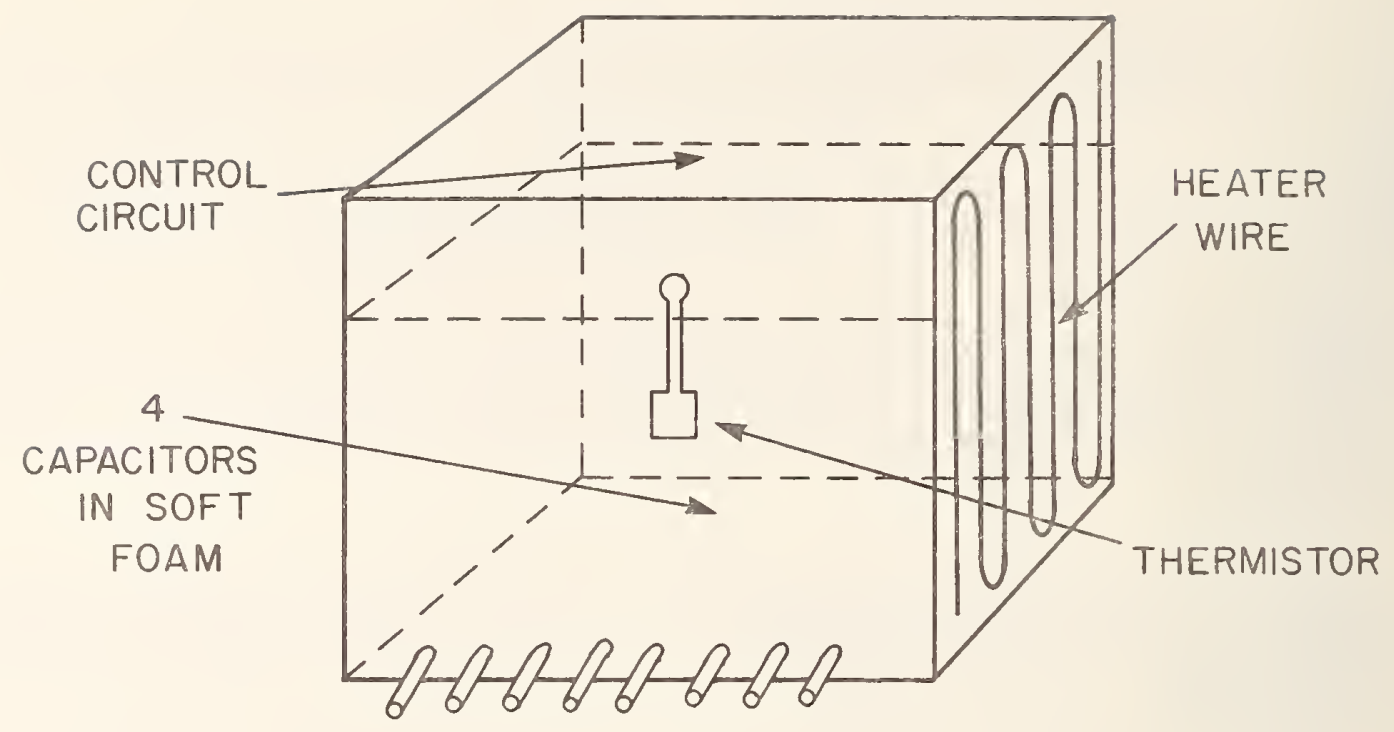

COAXIAL LEADS

FIG. 1 Schematic diagram of the aluminum box for housing the $1000 \mathrm{pF}$ transportable standard.

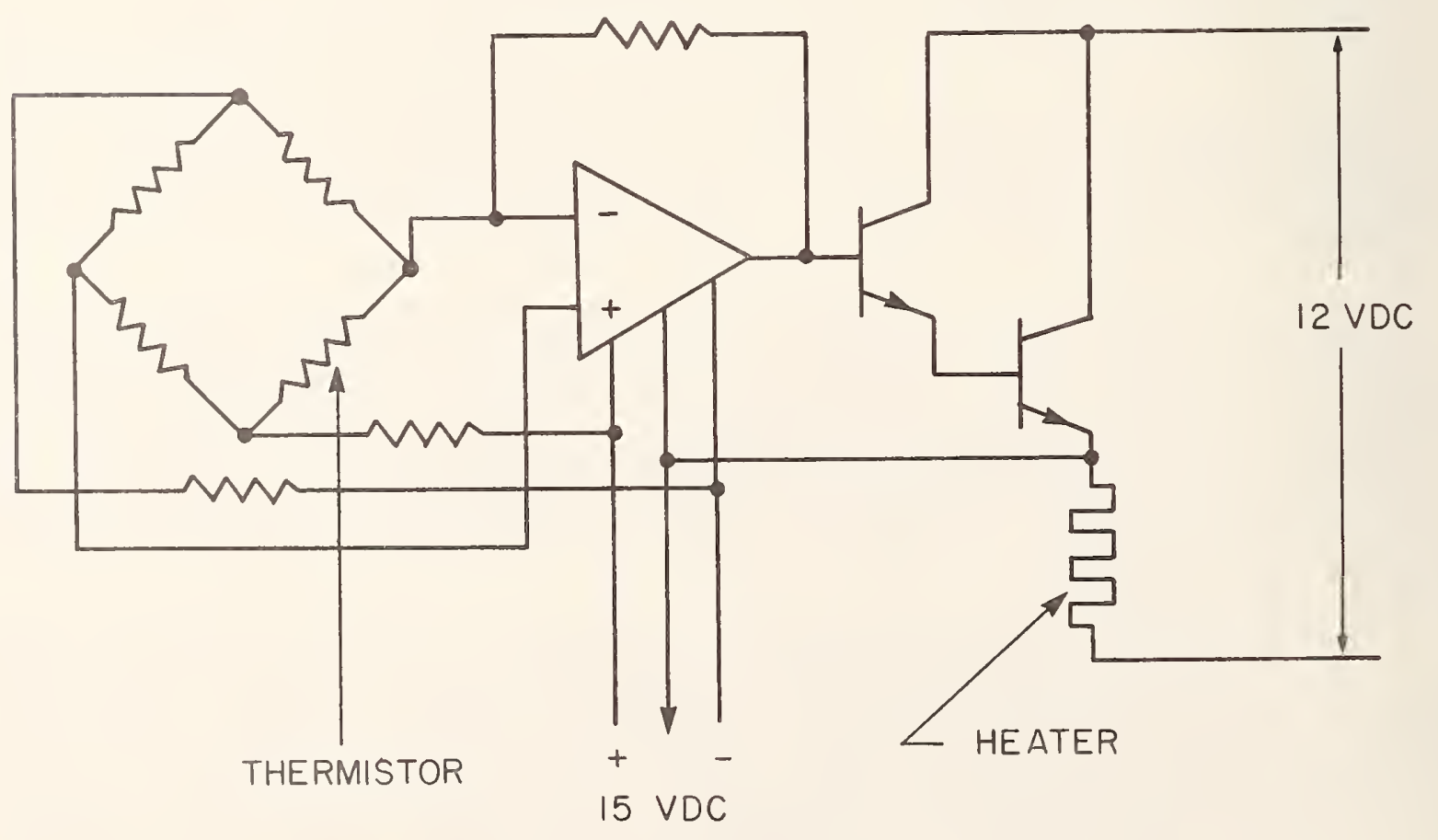

FIG. 2 Schematic diagram of heater control circuit. 
resolution of the measuring system is $+0.001 \mathrm{ppm}$. The range of capacitance change, $C(M A X)-C(M I N)$, for each standard is given in the first row of the table.

Table 2 is based upon the same data as Table 1 but the measured values are represented by the equation $y=\alpha+\beta t+\gamma \Delta T$ using a least squares fit. In this equation y is the departure from the nominal capacitance value (in ppm) after a time t (in days), and for the temperature increment $\Delta T$ (degrees celsius) which is the departure of the box temperature from the nominal control temperature, or $\Delta T=T_{B o x}-30.00{ }^{\circ} \mathrm{C}$. The paramters $\alpha, \beta$, and $\gamma$ are, respectively, the residual capacitance offset (ppm), the daily drift rate (ppm/day), and the temperature coefficient $\left(p p m /{ }^{0} \mathrm{C}\right)$.

Comparisons of the residual standard deviation o(RES) with the standard deviation of an individual measurement $\sigma$ (Ind. Meas.) of Table 1 indicates that this equation fits the performance of the capacitors quite well. The range of temperature variations of the standards during this test was $0.005{ }^{\circ} \mathrm{C}$. The similarity of $\sigma(M E A N)$ in Table 1 and $\sigma(R E S)$ in Table 2 indicates that over a short period of time (one month) the values of the standards could be calculated either from the mean of a set of measurements or by using a linear fit.

The methods used to test mechanical stability of individual capacitors could not be applid to the entire transport standard because of its size and weight. Mechanical stability was determined through actual shipment of the box to laboratories. In this evaluation the capacitors were shipped five times to various parts of the United States. All shipping was by air freight with hand carried delivery service to and from the airports. The transport standard was shipped under battery power for temperature control. No care was taken to ensure that the shipping container received special handling by the airlines. With data from shock recorders on similar boxes it was surmised that the container might well experience forces exceeding $45 \mathrm{~g}$ during transport. Table 3 indicates the effects of travel on the standards.

The numbers given are absolute values, the sign of the change being disregarded. Actual changes were both positive and negative, thus the change in the box mean is generally less than the changes in individual capacitors. The columns indicate changes due to one complete round trip. Each change was calculated as $C_{B}-C_{A}=$ change, where $C_{B}$ is the value before shipment and $C_{A}$ is the value after shipment. The last row of the table indicates the changes $C_{B}-C_{A}$, where $C_{B}$ is the value of each standard at the start of testing and $C_{A}$ is the value of each capacitor nine months later. As a general rule, the larger changes occurred in all capacitors on the same transfer. 
TABLE 1 .

\begin{tabular}{|c|c|c|c|c|c|c|}
\hline \multirow[t]{2}{*}{ Parameter } & & \multicolumn{5}{|c|}{ Capacitors } \\
\hline & & $\begin{array}{l}A 1 \\
(p p m)\end{array}$ & $\begin{array}{l}A 2 \\
(p p m)\end{array}$ & $\begin{array}{l}A 3 \\
(p p m)\end{array}$ & $\begin{array}{l}\text { A4 } \\
(p p m)\end{array}$ & $\begin{array}{l}\text { Mean } \\
\text { (ppm) }\end{array}$ \\
\hline Range & & 0.022 & 0.080 & 0.064 & 0.036 & 0.046 \\
\hline o(Individual & Measurement) & 0.009 & 0.020 & 0.020 & 0.012 & 0.015 \\
\hline \multirow[t]{4}{*}{$\sigma($ Mean $)$} & & 0.003 & 0.007 & 0.007 & 0.004 & 0.005 \\
\hline & & TABLE 2 & & & & \\
\hline & DAILY VALUES & FITTED & TO $\alpha+\beta t$ & $+\gamma \Delta T$ & & \\
\hline & & A 1 & A2 & & A3 & A 4 \\
\hline \multicolumn{2}{|l|}{$\alpha(p p m)$} & -147.290 & -270.11 & -3 & 25.593 & -172.455 \\
\hline \multicolumn{2}{|l|}{$\beta(p p m / d a y)$} & -0.0012 & -0.0030 & & .0027 & -0.0021 \\
\hline \multicolumn{2}{|l|}{$\gamma\left(p p m /{ }^{0} \mathrm{C}\right)$} & 3.2667 & 2.8826 & & .6822 & 3.8676 \\
\hline \multicolumn{2}{|l|}{$\sigma(R E S)(p p m)$} & 0.006 & 0.004 & & .006 & 0.004 \\
\hline
\end{tabular}

TABLE 3 .

CHANGES IN CAPACITANCE DUE TO SHIPMENT

$\begin{array}{ccccc}A 1 & A 2 & A 3 & A 4 & \text { Mean } \\ (p p m) & (p p m) & (p p m) & (p p m) & (p p m)\end{array}$

Min. Change

$\begin{array}{lllll}0.071 & 0.047 & 0.030 & 0.020 & 0.009\end{array}$

Max. Change

$\begin{array}{lllll}0.388 & 0.162 & 0.209 & 0.111 & 0.180\end{array}$

Ave. Change

$\begin{array}{llll}0.194 & 0.104 & 0.083 & 0.061\end{array}$

0.069

Change for 9 Months

$\begin{array}{llll}0.123 & 0.426 & 0.193 & 0.081\end{array}$ 
In one shipment, capacitor A3 changed 1.24 ppm. This value was not included in Table 3, since in a normal MAP procedure, this change would be sufficient to cause this capacitor to be excluded from all calculations.

\section{Conclusion}

Calibrations using the transport standard appear to offer significant improvement over the normal method of shipping capacitors to NBS. At present, a 5-ppm uncertainty in value must be assigned to capacitors shipped to NBS for calibration; a major portion of this uncertainty is an allowance for changes due to shipping. Using the transport standard, this uncertainty can be reduced by approximately one order of magnitude.

There are several improvements that will be made on future transport standards. For example, the enclosure is too heavy and bulky for easy handling. Thus a reduction in both weight and size will be attempted.

The capacitors used were not initially tested for frequency response. Since they have varying degrees of frequency dependence, their range of applicability is limited. The conductances of these capacitors are higher than normal indicating that greater care must be taken in the assembly of the package on future versions.

The temperature coefficients and drift rates of the capacitors were calculated for a period of time between shipments. A further study will be carried out to see if these coefficients remain unchanged over the time interval of two measurement periods with shipment of the standards in between. If the coefficients do remain constant, a further reduction in the uncertainty of predicted values for the standards will be justified.

\section{Acknowledgements}

The authors would like to thank Mr. Robert E. Long and Mr. Charles Levy for their help in the construction and testing of the transport standard.

\section{References}

(1) Cutkosky, Robert D. Capacitance bridge-NBS type 2. Nat. Bur. Stand. Report No. $7103,1961$.

(2) Cutkosky, Robert D. Actual and passive direct reading ratio sets for comparison of audio-frequency admittances. J. Res. Nat. Bur. Stand., 68(4):227-236;1964 0ctober. Vol.68C, No. 4 , October 1964 . 
Capacitors are exposed to a variety of mechanical shocks during use in the laboratory or during shipment. Great care in packing standard capacitors will, at most, reduce the intensity of the shock incurred in shipment; in the laboratory, a capacitor receives some degree of shock every time it is moved. Capacitors of the type used in the transport box have parallel plates fixed in position by support rods. Mechanical shock tends to change the geometry of the plates or the position of the plates relative to the enclosure.

The mechanical stability of the standards was of utmost importance since it was intended that they be shipped from six to ten times annually. Therefore, six tests of stability were devised to select those standards most suitable for shipment. since only a limited number of capacitors were available as candidates for testing the transport box, absolute limits of performance could not be established. Instead, those capacitors of the available groups which appeared to be "best" were chosen.

The six tests used were designated as ORIENTATION, SMALL ANGLE, TILT, SOFT KNOCK, HARD KNOCK and DROP TESTS. The test protocols and the changes of capacitance measured are outlined below.

ORIENTATION: The capacitor is measured while in an upright (vertical) position and while in the four posible horizontal positions. The maximum difference with all measurements considered is determined. Any change greater than 10 ppm is usually evidence of a faulty capacitor. This test was used to determine gross instability.

SMALL ANGLE: The capacitor is measured in the upright position and on a $3^{0}$ inclined plane. Four measurements are made on the inclined plane with the capacitor being rotated $90^{\circ}$ (around the vertical axis) after each measurement. The maximum difference with all measurements considered is determined. Since most laboratory tables are not exactly horizontal, the offset from horizontal would cause error if the capacitor were excessively sensitive. Differences of several tenths of a ppm were evident in some capacitors. Only those with a negligible change were used in the box.

TILT: After measurement of capacitance in the upright position the capacitor is tilted $90^{\circ}$ and returned to the upright position for the second measurement. The test is repeated for each side and the bottom of the capacitor, i.e.s five tests in a11. The net difference C(UPRIGHT) 1 - C(UPRIGHT) 2 is determined. since changes with position should be completely reversible for a good capacitor, any measurable net change was cause for rejection.

SOFT KNOCK: The capacitor is measured before and after being struck by the head of a pendulum. The head is covered with 
soft rubber. The force generated by the pendulum is roughly equivalent to that generated by a mild wrist action motion of the human hand. The force is in a horizontal plane and it is applied to the four sides and corners of the capacitor. The differences $C(B E F O R E)$ - C (AFTER) are determined. A minimum change was the criterion for selection of capacitors from those available as candidates.

HARD KNOCK: The test procedure is the same as that for sOFT KNOCK with the exception that the soft rubber head is replaced by a hard plastic head. In the SOFT KNOCK test the force has a relatively long duration with a gaussian-like shape; in the HARD KNOCK the force tends to be impulsive with a more abrupt rise and fall.

DROP TEST: The capacitor is measured in the upright position. A 2" plate is inserted under one side of the capacitor raising that side off the table. The plate is quickly removed allowing the capacitor to drop back in its initial upright position and the capacitance is measured again. Differences C(UPRIGHT) C(UPRIGHT) 2 are determined for tests repeated for the four sides of the capacitor. The applied impulse is in the vertical direction. Capacitors were chosen on the basis of minmum change in this test.

The results of these sixtests for a large number of $1000 \mathrm{pF}$ capacitors are shown in Figures 3-8. Many capacitors not specifically considered for the transport standard are included and, therefore, these graphs indicate the general performance of the 1000 pF capacitors.

The graphs are histograms for the various tests. The $Y$ axis gives the percentage of capacitors which fall into specific ranges of maximum change given by the $X$ axis. The $X$ axis has a 1 imit of either $20 \mathrm{ppm}$ (Figure 3) or 2 ppm (Figures 4-8). The tests revealed a few capacitors with changes far bayond these limits. In these cases the position of the mark on the graphs relative to the limiting value indicate only that they are beyond the limit and are not intended to show the actual change measured. 


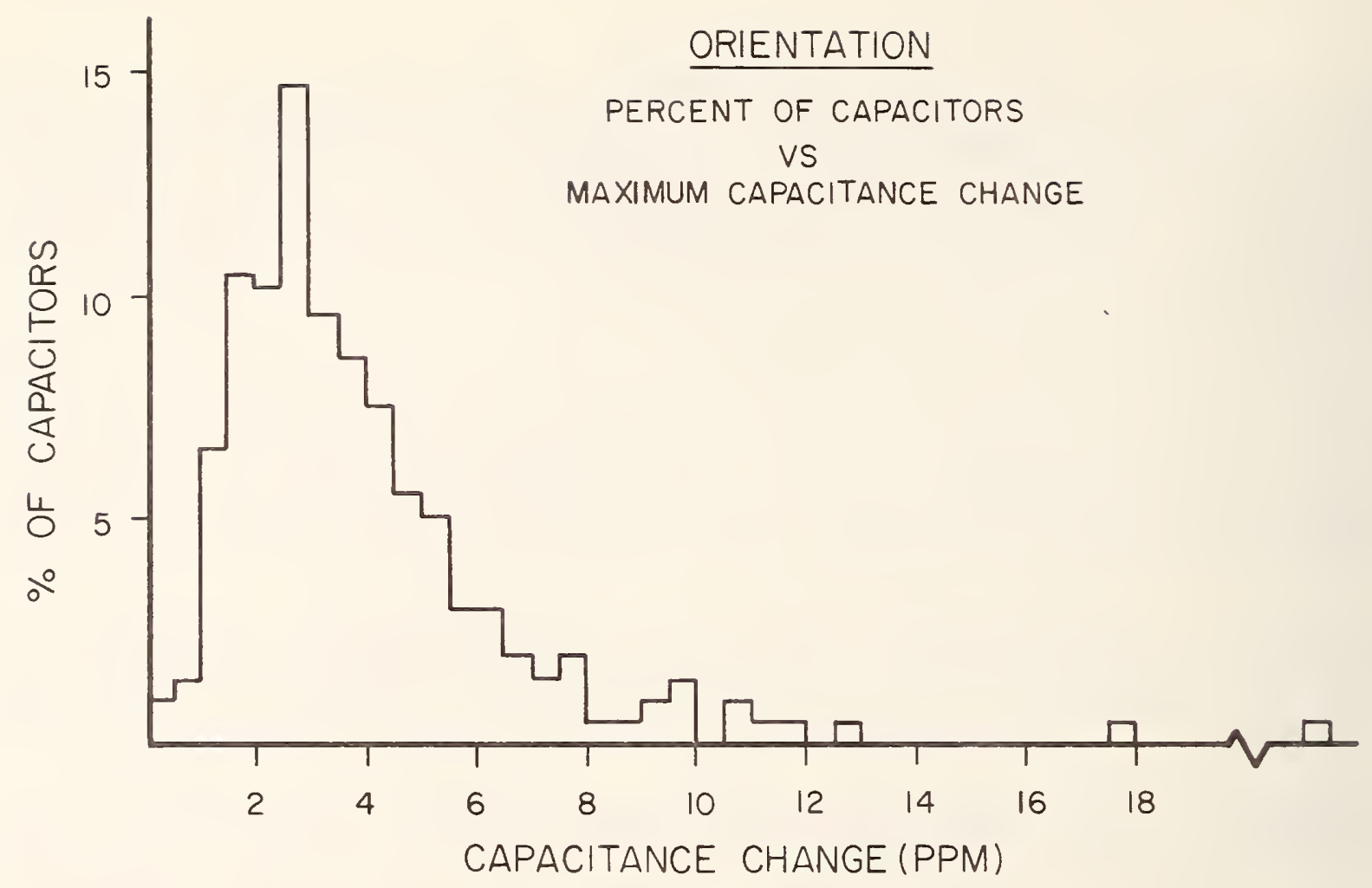

FIG.3 Histogram of the fractional numbers of capacitors for which different values of maximum capacity change were caused by the Orientation Test.

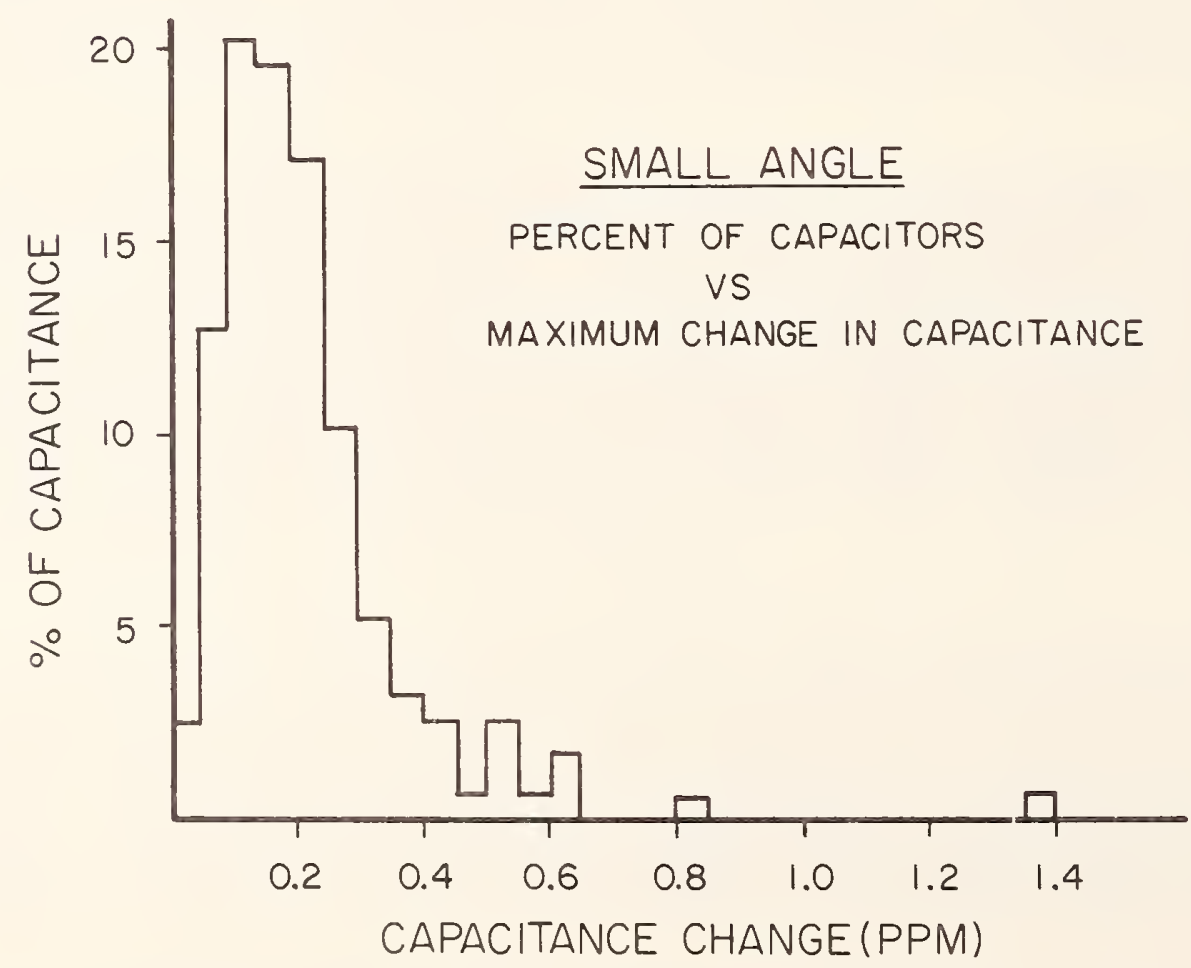

FIG.4 Histogram of the fractional numbers of capacitors for which different values of maximum capacity change were caused by the Small Angle Test. 


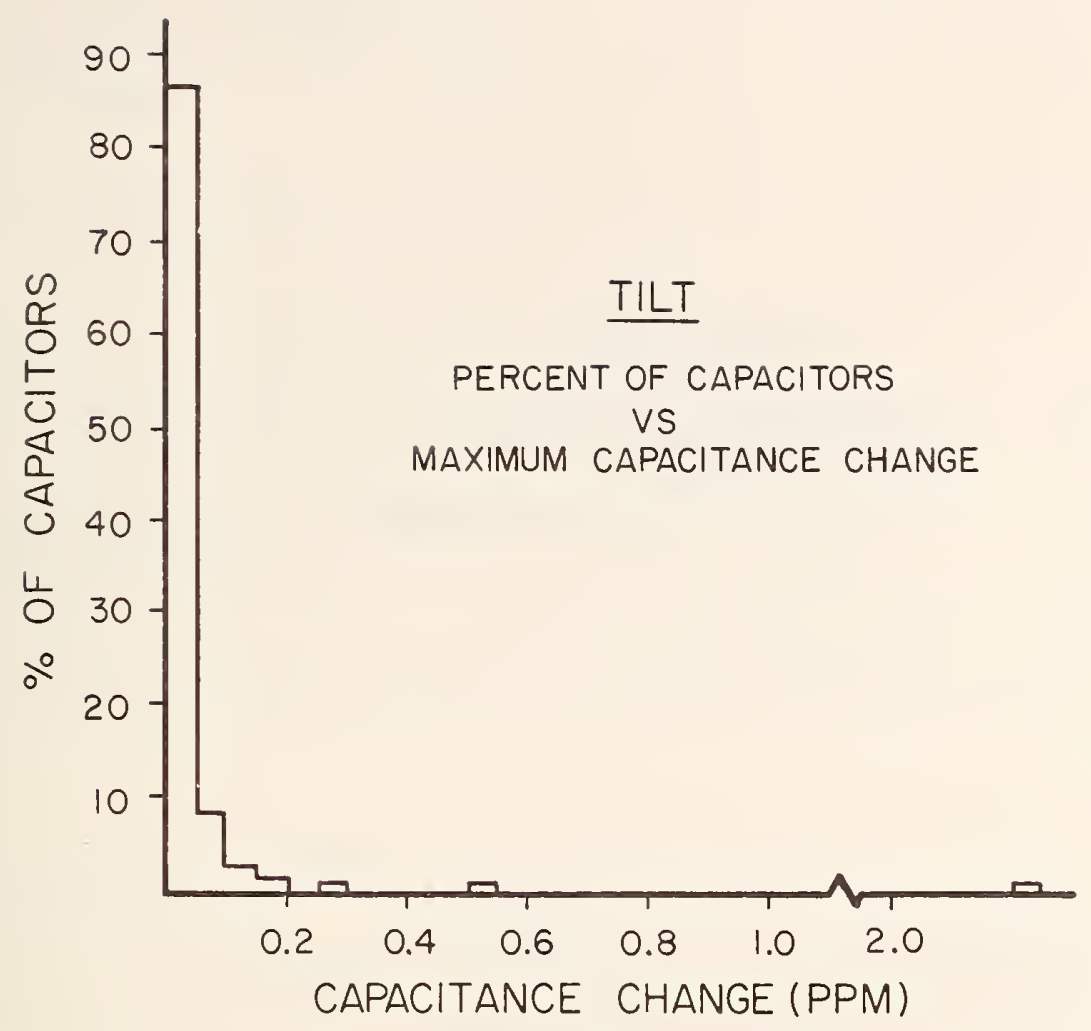

FIG. 5 Histogram of the fractional numbers of capacitors for which different values of capacity change were caused by the Tilt Test

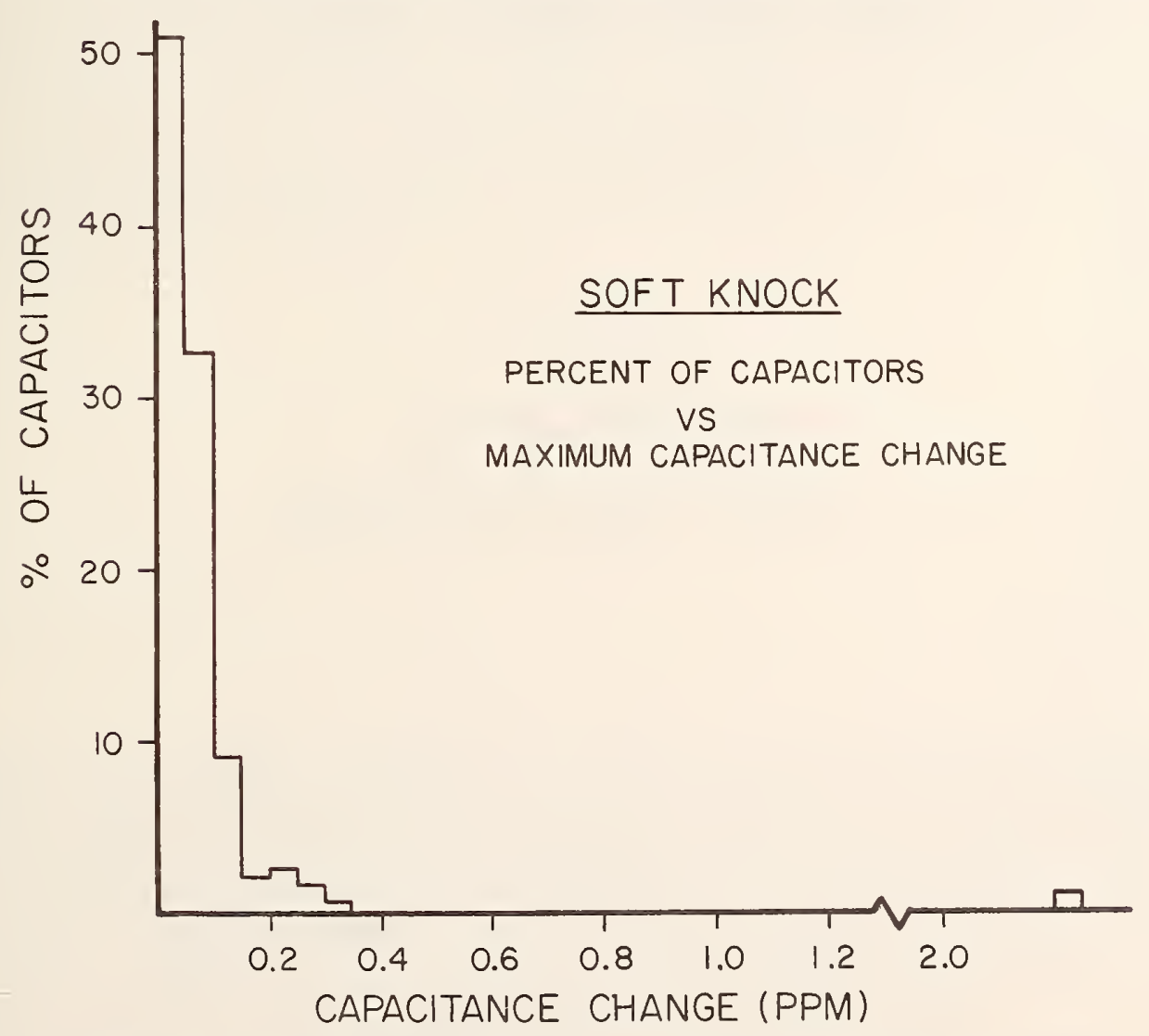

FIG. 6 Histogram of the fractional numbers of capacitors for which different values of maximum capacity change were caused by the Soft Knock Test. 


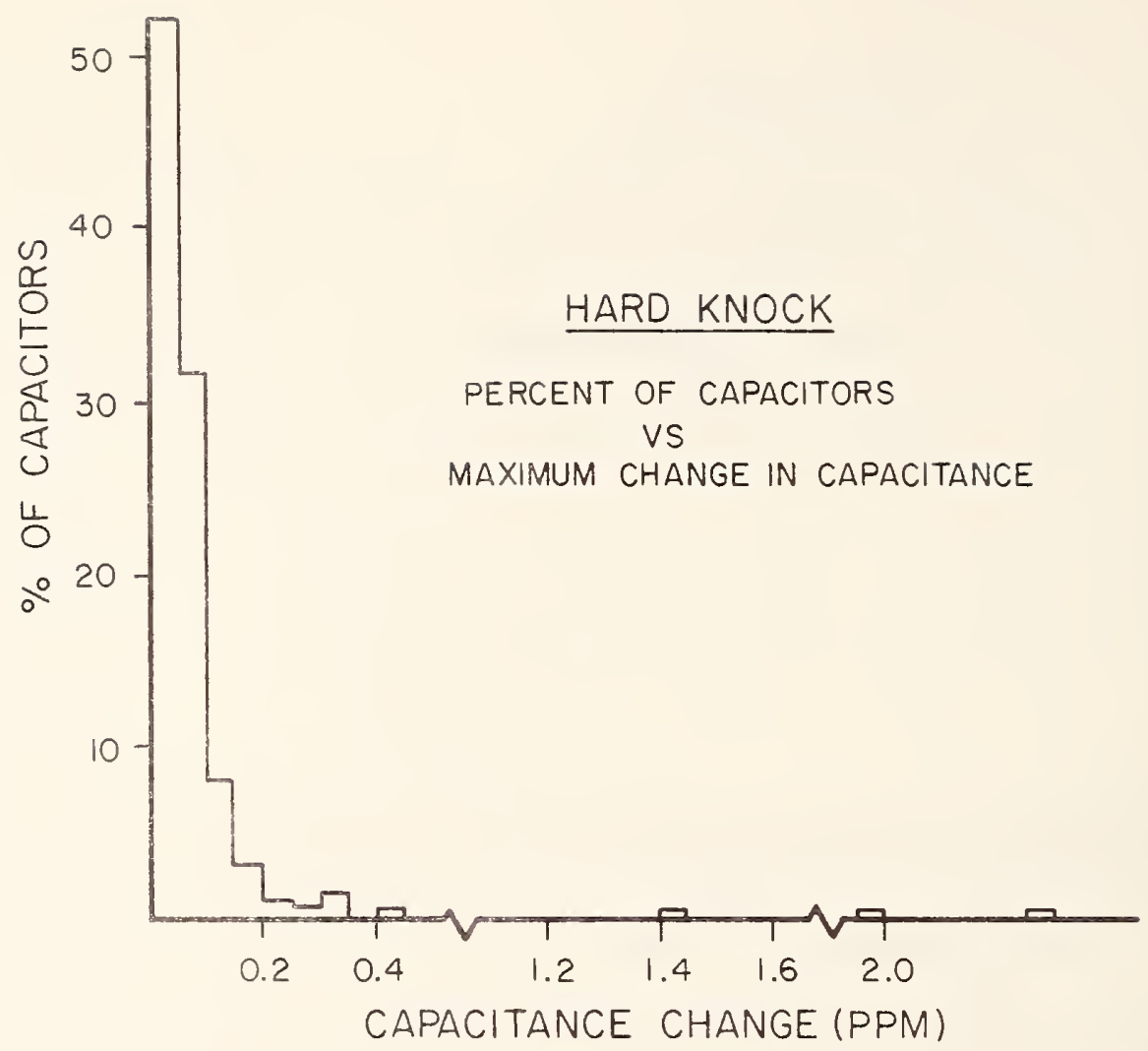

FIG. 7 Histogram of the fractional numbers of capacitors for which different values of maximum capacity change were caused by the Hard Knock Test.

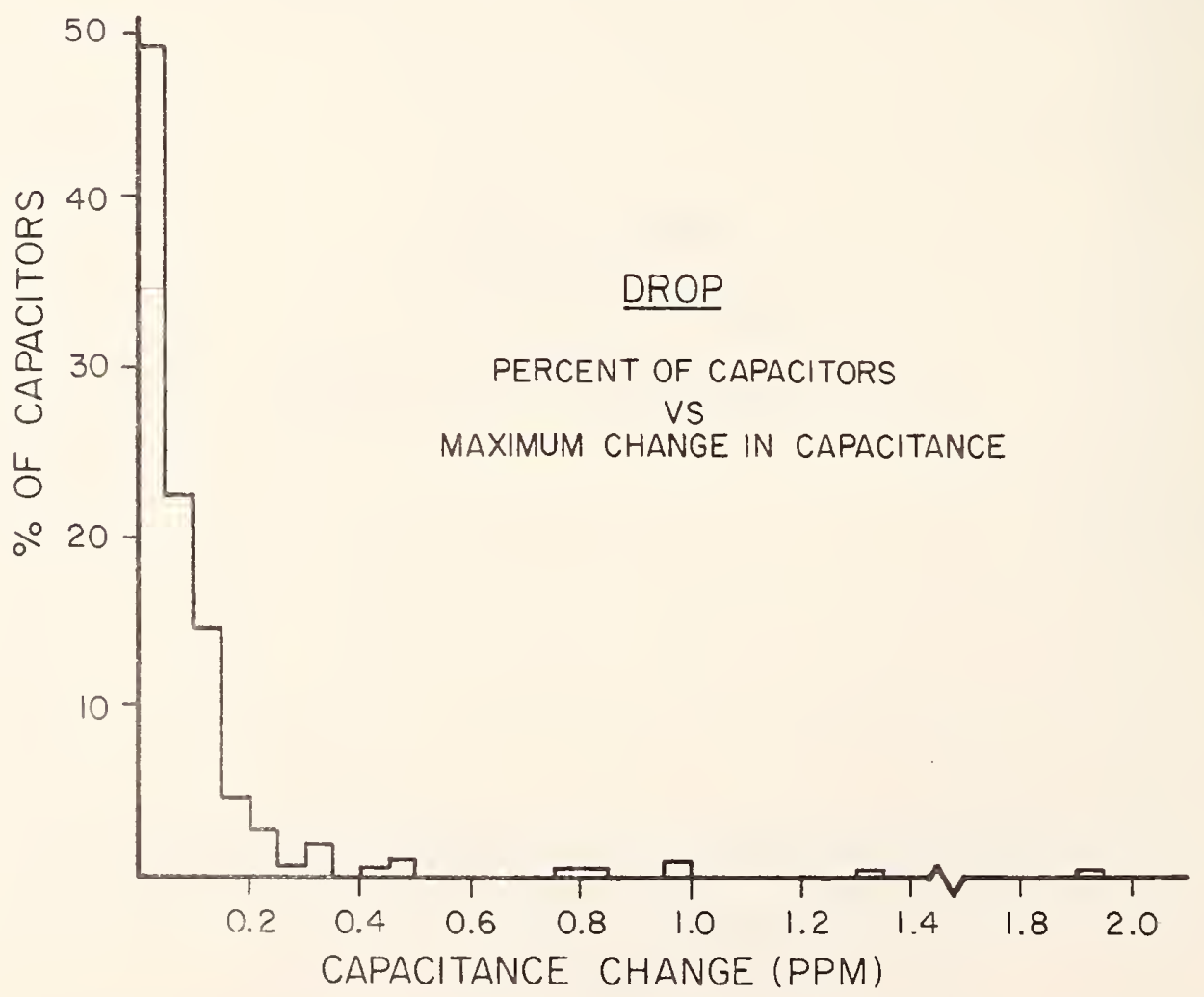

FIG. 8 Histogram of the fractional numbers of capacitors for which different values of maximum capacity were caused by the Drop Test. 
NBS-114A (REV. 2-8C)

U.S. DEPT. OF COMM.

BIBLIOGRAPHIC DATA

SHEET (See instructions)

4. TITLE AND SUBTITLE

Transportable 1000 pF Standard for the NBS Capacitance Measurement Assurance Program

\section{AUTHORIS)}

George Free and Jerome Morrow

6. PERFORMING ORGANIZATION (If joint or other than NBS, see instructions)

7. Contracu Grant No.

NATIONAL BUREAU OF STANDARDS

DEPARTMENT OF COMMERCE

WASHINGTON, D.C. 20234

8. Type of Report \& Period Covered

XVXXX Final

9. SPONSORING ORGANIZATION NAME AND COMPLETE ADDRESS (Street, City, State, ZIP)

same as \#6

\section{SUPPLEMENTARY NOTES}

[] Document describes a computer program; SF-185, FIPS Sof tware Summary, is attached.

11. ABSTRACT (A 200-word or less factual summary of most significant information. If document includes a significant bibliography or literature survey, mention it here)

A capacitance transport standard has been constructed for use in the National Bureau of Standards Measurement Assurance Program. The transport standard was designed so that variations in ambient temperature and mechanical shock would have a minimal effect on the value of the internal reference capacitors. A significant improvement in stability of $1000 \mathrm{pF}$ capacitors during shipment and in the laboratory has been achieved through this design.

12. KEY WORDS (Six to twelve entries; alphabetical order; capitalize only proper names; and separate key words by semicolons) calibration; measurement assurance; measurement assurance programs; reference standards; standard capacitors; standard qualification; transfer standards.

13. AVAILABILITY

X. Unlimited

For Official Distribution. Do Not Release to NTIS

X Order From Superintendent of Documents, U.S. Government Printing Office, Washington, D.C. 20402.

Order From National Technical Information Service (NTIS), Springfield, VA. 2216I
14. NO. OF PRINTED PAGES 15

15. Price 



\section{NBS TECHNICAL PUBLICATIONS}

\section{PERIODICALS}

JOURNAL OF RESEARCH-The Journal of Research of the National Bureau of Standards reports NBS research and development in those disciplines of the physical and engineering sciences in which the Bureau is active. These include physics, chemistry, engineering, mathematics, and computer sciences. Papers cover a broad range of subjects, with major emphasis on measurement methodology and the basic technology underlying standardization. Also included from time- to time are survey articles on topics closely related to the Bureau's technical and scientific programs. As a special service to subscribers each issue contains complete citations to all recent Bureau publications in both NBS and nonNBS media. Issued six times a year. Annual subscription: domestic $\$ 18$; foreign $\$ 22.50$. Single copy, $\$ 4.25$ domestic; $\$ 5.35$ foreign.

\section{NONPERIODICALS}

Monographs-Major contributions to the technical literature on various subjects related to the Bureau's scientific and technical activities.

Handbooks-Recommended codes of engineering and industrial practice (including safety codes) developed in cosperation with interested industries, professional organizations, and regulatory bodies.

Special Publications-Include proceedings of conferences sponsored by NBS, NBS annual reports, and other special publications appropriate to this grouping such as wall charts, pocket cards, and bibliographies.

Applied Mathematics Series-Mathematical tables, manuals, and studies of special interest to physicists, engineers, chemists, biologists, mathematicians, computer programmers, and others engaged in scientific and technical work.

National Standard Reference Data Series-Provides quantitative data on the physical and chemical properties of materials, compiled from the world's literature and critically evaluated. Developed under a worldwide program coordinated by NBS under the authority of the National Standard Data Act (Public Law 90-396).

NOTE: The principal publication outlet for the foregoing data is the Journal of Physical and Chemical Reference Data (JPCRD) published quarterly for NBS by the American Chemical Society (ACS) and the American Institute of Physics (AIP). Subscriptions, reprints, and supplements available from ACS, 1155 Sixteenth St., NW, Washington, DC 20056.
Building Science Series-Disseminates technical information developed at the Bureau on building materials, components, systems, and whole structures. The series presents research results, test methods, and performance criteria related to the structural and environmental functions and the durability and safety characteristics of building elements and systems.

Technical Notes-Studies or reports which are complete in themselves but restrictive in their treatment of a subject. Analogous to monographs but not so comprehensive in scope or definitive in treatment of the subject area. Often serve as a vehicle for final reports of work performed at NBS under the sponsorship of other government agencies.

Voluntary Product Standards-Developed under procedures published by the Department of Commerce in Part 10, Title 15, of the Code of Federal Regulations. The standards establish nationally recognized requirements for products, and provide all concerned interests with a basis for common understanding of the characteristics of the products. NBS administers this program as a supplement to the activities of the private sector standardizing organizations.

Consumer Information Series-Practical information, based on NBS research and experience, covering areas of interest to the consumer. Easily understandable language and illustrations provide useful background knowledge for shopping in today's technological marketplace.

Order the above NBS publications from: Superintendent of Documents, Government Printing Office, Washington. DC 20402.

Order the following NBS publications-FIPS and NBSIR's-from the National Technical Information Services, Springfield, VA 22161.

Federal Information Processing Standards Publications (FIPS PUB)-Publications in this series collectively constitute the Federal Information Processing Standards Register. The Register serves as the official source of information in the Federal Government regarding standards issued by NBS pursuant to the Federal Property and Administrative Services Act of 1949 as amended, Public Law 89-306 (79 Stat. 1127), and as implemented by Executive Order 11717 (38 FR 12315, dated May 11, 1973) and Part 6 of Title 15 CFR (Code of Federal Regulations)

NBS Interagency Reports (NBSIR)-A special series of interim or final reports on work performed by NBS for outside sponsors (both government and non-government). In general, initial distribution is handled by the sponsor: pub!ic distribution is by the National Technical Information Services, Springfield, VA 22161. in paper copy or microfiche form. 
Washington, D.C. 20234

Official Business

Penalty for Private Use $\$ 300$

POSTAGE AND FEES PAID U.S. DEPARTMENT OF COMMERCE COM-215

FIRST CLASS 